\title{
UDC 543.4:542.61:546.72 \\ SPECTROPHOTOMETRIC DETERMINATION OF IRON(III) WITH 3-((2-HYDROXYPHENYL)DIAZENYL)PENTADIONE-2,4 AND DIANTIPYRYLMETHANE
}

\author{
A.Y.Abiyeva, F.V.Kuliyeva, Kh.J.Nagiyev, A.Q.Babayev, F.M.Chyragov \\ Baku State University \\ xalil-71@rambler.ru
}

Received 10.10.2018

\begin{abstract}
The complex formation of iron(III) with 3-((2-hydroxyphenyl)diazenyl)pentadione-2,4 and diantipyrylmethane was investigated by spectrophotometric method and highly selective method of determination of its microamounts in natural objects established. It's found that at $\mathrm{pH} 2.0-2.5$ in the presence of diantipyrylmethane $\mathrm{Fe}(\mathrm{III})$ forms with reagent intensively colored mixed-ligand complex Fe(III)-R-DAM with the ratio of components 1:2:1. During formation of mixed-ligand complex bathochromic shift and hyperchromic effect are observed compared to binary complex. The optimum conditions of formation of same and mixed-ligand complexes of Fe(III) were determined and the main spectrophotometric characteristics calculated. By spectrophotometric method stability constants of complexes are determined and found that mixed-ligand complex $\mathrm{Fe}(\mathrm{III})-\mathrm{R}-\mathrm{DAM}$ has high stability: $\lg \beta(\mathrm{Fe}-\mathrm{R})=5.76 \pm 0.10 ; \quad \lg \beta(\mathrm{Fe}-\mathrm{R}-$ $\mathrm{DAM})=14.65 \pm 0.26$. The new highly selectivity spectrophotometric method for the determination of iron(III) has been developed and applied for the determination of its quantity in volcanic mountain rocks.
\end{abstract}

Keywords: iron(III), 3-((2-hydroxyphenyl)diazenyl)pentadione-2,4, diantipyrylmethane, volcanic mountain rock.

https://doi.org/10.32737/0005-2531-2019-2-40-43

In connection with the higher chemical and analytical characteristics compared to the corresponding appropriate complexes, the formation reactions of the various complexes are widely used in analytical chemistry, especially in spectrophotometric analysis [1-3]. These reactions have higher sensitivity and selectivity and in some cases they are able to directly determine the trace components in samples of complex composition $[4,5]$. We have so far proposed a number of methods for the determination of various metal ions, which have high analytical characteristics, including methods based on the formation of different ligand complexes of iron(III) [6-9]. In the present study, the complex formation of iron(III) with 3-((2-hydroxyphenyl)diazenyl)pentadione-2,4 was investigated by a spectrophotometric method and a new selective method was developed for its determination in samples of complex composition.

\section{Experimental part}

Reagents and solutions. The standard solution of $1.0 \cdot 10^{-1} \mathrm{M}$ iron(III) was prepared by solving the calculated sample weight of iron metal in chloride acid (1:1) with addition of nitric acid [10]. The working solution of $2.0 \cdot 10^{-3}$
$\mathrm{M}$ iron(III), used in the work has been prepared by rinsing standard solution with distilled water before use.

The $2.0 \cdot 10^{-3} \mathrm{M}$ solutions of diantipyrylmethane (DAM) and 3-((2-hydroxyphenyl)diazenyl)pentadione-2,4 (R), used in the study were prepared by solving their calculated sample weights in ethanol. Acetate-ammonia buffer solutions $(\mathrm{pH} 3-11)$ and $\mathrm{HCl}$ fiksanal $(\mathrm{pH} 0-2)$ were used to create a suitable acidity environment. All used reagents were of analytical grade.

Equipment. The Lambda-40 spectrophotometer of "Perkin Elmer" company equipped with a computer and the KFK-2 photoelectric calorimeter were used for spectrophotometric research in UV and visible regions. The optical density of the solutions was measured using $l=1.0 \mathrm{~cm}$ thick tubes. The acidity of the solutions was controlled by using $\mathrm{pH}-121 \mathrm{pH}-$ meter with glass electrode.

Methods. Various amounts of iron(III) salt with a final concentration of 0.34 to 4.48 $\mathrm{mkg} / \mathrm{ml}$ were poured in measuring tubes with a volume of $25 \mathrm{ml}, 2.5 \mathrm{ml}$ of $2.0 \cdot 10^{-3} \mathrm{M}$ reagent solution and $1.5 \mathrm{ml}$ of $2.0 \cdot 10^{-3} \mathrm{M}$ diantipyrylmethane solution were added and diluted to 
mark with $0.01 \mathrm{M} \mathrm{HCl}(\mathrm{pH} 2.0)$ solution. Analogically, the "blind practice" (R+DAM) solution was prepared. The optical density of the prepared solutions was measured at KFK-2 photoelectric calorimeter in $l=1.0 \mathrm{~cm}$ thickness in the background of the "blind experience" at wavelength $\lambda=490 \mathrm{~nm}$.

\section{Results and discussion}

Iron(III) interact with 3-((2-hydroxyphenyl)diazenyl)pentadione- 2,4 in $\mathrm{pH} 1.0-8.0$ acidity medium and forms intensive color complex compound at maximum light absorption $\lambda=434 \mathrm{~nm}$ (Figure 1). The complex has the maximum yield at $\mathrm{pH}=4.5-5.0$ acidic environment (Figure 2). Reagent has a maximum absorption of light in an acidic environment $(\mathrm{pH}$ 1.0-7.0) at wavelength $\lambda=382 \mathrm{~nm}$. The addition of diantipyrylmethane to the $\mathrm{Fe}$ (III)-R complex solution creates a different ligand complex Fe(III)-R-DAM, resulting in a batochromic shifting and hyperchromic effect in the absorption spectrum, as well as the maximum shift of the maximum yield to a more acidic environment. The maximum light absorption of the $\mathrm{Fe}$ (III)-R-DAM different ligand complex corresponds to the wavelength $\lambda=476 \mathrm{~nm}$ (Figure 1). $\mathrm{pH}_{\mathrm{opt}}=2.0-2.5$. The absorption spectra of the complexes were also studied in the background of the "blind experience" ( $\mathrm{R}$ and $\mathrm{R}+\mathrm{DAM}$ ) because the color of the reagent and complexes various depending on the acidity of

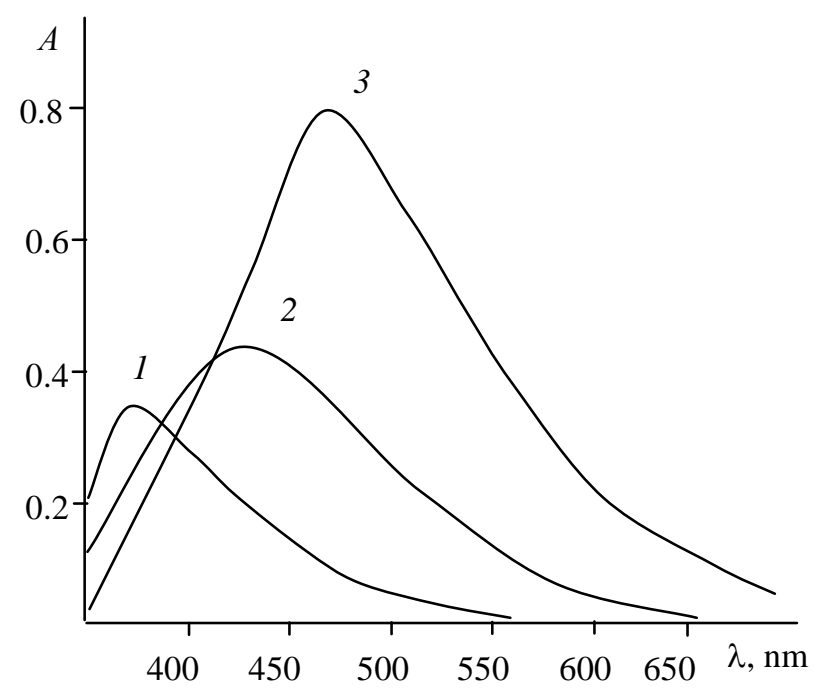

Fig. 1. Absorption spectra of iron(III) complexes in $\mathrm{pH}_{\mathrm{opt}}$ acidic medium: $1-\mathrm{R}, 2-\mathrm{Fe}$ (III)-R, $3-\mathrm{Fe}$ (III)-RDAM; $C_{\mathrm{Fe}}=8.0 \cdot 10^{-5} \mathrm{M}, C_{\mathrm{R}}=2.0 \cdot 10^{-4} \mathrm{M}, C_{\mathrm{DAM}}=1.2 \cdot 10^{-4} \mathrm{M}$; Lambda- $40, l=1.0 \mathrm{~cm}$. the environment. It has been established that the same and different ligand complexes of iron have maximum light absorption in the background of "blind experience" at $\lambda=490 \mathrm{~nm}$.

In order to determine the optimal conditions for formation the effects of components concentration, time and temperature on the complex formation were investigated. It has been established that for the formation of the $\mathrm{Fe}$ (III)- $\mathrm{R}$ complex the $2.0 \cdot 10^{-4} \mathrm{M}$ of reagent and for the formation of the Fe(III)-R-DAM complex the $2.0 \cdot 10^{-4} \mathrm{M}$ of reagent and $1.2 \cdot 10^{-4} \mathrm{M}$ concentration of diantipyrylmethane is required. The optical density of the same ligand complex remains constant at 2.5-10.0, of the different ligand complex at about 2.5-10.0 and 1.5-8.0 times higher of concentrations of the reagent and diantipyrylmethane respectively. Despite the fact that both iron(III) complexes are formed by mixing component's solutions they differ from each other in solution by stability. The Fe(III)-R-DAM complex maintains its optical density at a temperature of up to $80^{\circ} \mathrm{C}$ during one day, while the $\mathrm{Fe}(\mathrm{III})-\mathrm{R}$ complex is stable in the solution for 2 hours and up to $60^{\circ}$ temperature.

The ratio of components in the composition of the studied complexes was determined by the methods of equilibrium shift, relative output of Starik-Barbanel and izomolar series [11].

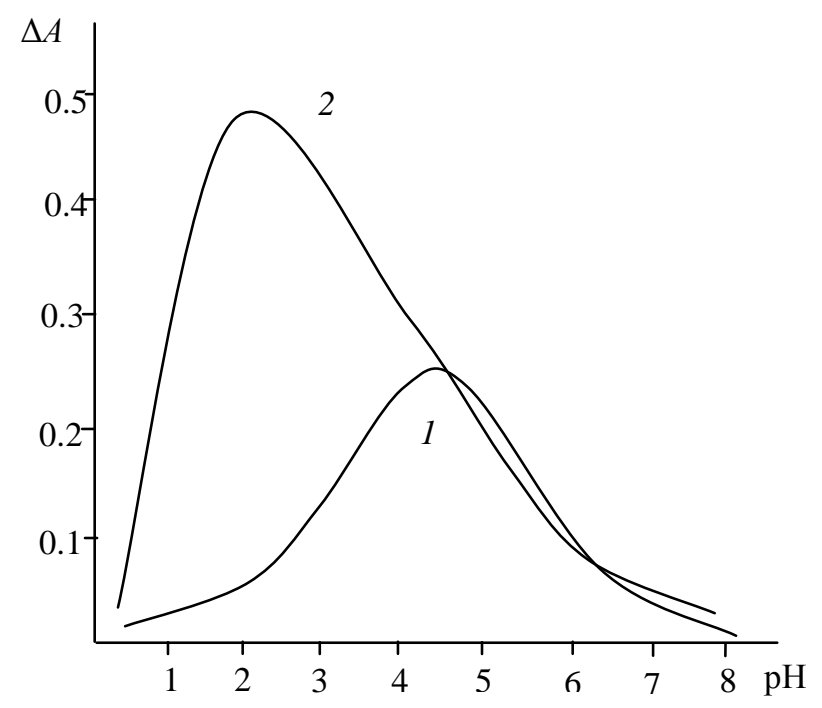

Fig. 2. Dependence of light absorption of iron(III) complexes on $\mathrm{pH}$ on the background of the "blind experience": 1 - Fe(III)-R, 2 - Fe(III)-R-DAM; $C_{\mathrm{Fe}}=8.0 \cdot 10^{-5} \mathrm{M}, C_{\mathrm{R}}=2.0 \cdot 10^{-4} \mathrm{M}, C_{\mathrm{DAM}}=1.2 \cdot 10^{-4} \mathrm{M}$; $\mathrm{KFK}-2, l=1.0 \mathrm{~cm}$. 
The results of all three methods showed that the ratio of components in the composition of the $\mathrm{Fe}$ (III)-R complex was $1: 2$ and in $\mathrm{Fe}(\mathrm{III})-\mathrm{R}-$ DAM complex 1:2:1 (Table 1). The number of $\mathrm{H}^{+}$ ions allocated during the formation of complexes was determined by Astakhov method and the results of the ratio of the components in their composition were confirmed [12].

Stability constants of complexes were determined by the spectrophotometric method and the $\mathrm{Fe}$ (III)-R-DAM different ligand complex was found to have a higher stability: $\lg \beta(\mathrm{Fe}-$ $\mathrm{R})=5.76 \pm 0.10 ; \lg \beta(\mathrm{Fe}-\mathrm{R}-\mathrm{DAM})=14.65 \pm 0.26$.

During the determination of the iron in the form of $\mathrm{Fe}(\mathrm{III})-\mathrm{R}$ and $\mathrm{Fe}(\mathrm{III})-\mathrm{R}-\mathrm{DAM}$ complexes, the Ber law is observed into its range of $0.45-4.48$ and $0.34-4.48 \mathrm{mg} / \mathrm{ml}$ respectively. The equations of the established graphs using the least squares method have been determined [13]. $\mathrm{Fe}(\mathrm{III})-\mathrm{R} ; \mathrm{A}=(0.110 \pm 0.005) \cdot C+(1.43 \pm 0.08) \cdot 10^{-3}$, $\mathrm{Fe}(\mathrm{III})-\mathrm{R}-\mathrm{DAM} ; \quad \mathrm{A}=(0.410 \pm 0.009) \cdot C+(6.20 \pm$ $0.27) \cdot 10^{-4}$.

The molar absorption coefficient of the $\mathrm{Fe}$ (III)-R and $\mathrm{Fe}$ (III)-R-DAM complexes at a wavelength $\lambda_{\text {opt }}$ is equal to $(3.10 \pm 0.06) \cdot 10^{3}$ and $(6.00 \pm 0.10) \cdot 10^{3}$, respectively.

The effect of the foreign ions and masking agents for determination of iron(III) in the form of the same and different ligand complexes was studied and the determination method on the basis of the complex formation was found to have higher selectivity. To determine Fe(III)R-DAM as a complex, do not interfere a 5000fold amounts of alkali, alkaline-earth metals and rare earth elements; 1000-fold of $\mathrm{Mg}(\mathrm{II})$, $\mathrm{Co}(\mathrm{II}), \mathrm{Ni}(\mathrm{II}), \mathrm{Mn}(\mathrm{II}), \mathrm{Pb}(\mathrm{II}), \mathrm{Cd}(\mathrm{II}), \mathrm{Zn}(\mathrm{II})$, $\mathrm{Cu}$ (II), $\mathrm{Cr}$ (III); 600-fold of $\mathrm{Al}(\mathrm{III}), \mathrm{Ga}(\mathrm{III})$, İn(III), Ti(IV), Th(IV), V(V), U(VI) and 50fold of $\mathrm{Zr}(\mathrm{IV}), \mathrm{Hf}(\mathrm{IV}), \mathrm{Mo}(\mathrm{VI})$ and $\mathrm{W}(\mathrm{VI})$ ions.

The developed method was applied for determining the amount of iron in volcanic mountain rocks of the Lesser Caucasus, taken from Kalbajar region of Azerbaijan Republic.

A sample of 5.0 grams of rock was weighted on analytical scale and dissolved by heating in $20 \mathrm{ml}$ of $\mathrm{HF}+15 \mathrm{ml} \mathrm{HCl}+5 \mathrm{ml}$ $\mathrm{HNO}_{3}$ mixture to form a paste in graphite chamber. The obtained paste was processed until the complete sublimation of the residue of hydrogen-fluoride with $4-5 \mathrm{ml}$ of $\mathrm{HNO}_{3}$ at a temperature of $60-70^{\circ} \mathrm{C}$. The remaining residue was then dissolved in distilled water and insoluble part separated filtered through filter paper. The separated solution was transferred to a $50 \mathrm{ml}$ measuring tube and diluted to mark with distilled water. Different aliquot parts were removed from the prepared solution and transferred to a $25 \mathrm{ml}$ measuring tube and by adding a reactive and diantipyrylmethane solution in the amount corresponding to the maximum yield of the $\mathrm{Fe}$ (III)-R-DAM complex was diluted to mark with $0.01 \mathrm{M} \mathrm{HCl}(\mathrm{pH} 2.0)$ solution. The optical density of the prepared solutions was measured in the order described in the method and the amount of iron was determined according to the graduated degree graph. The results of determination are given in Table 2.

Table 1. Chemical and analytical characteristics of iron(III) complexes with 3-((2-hydroxyphenyl)diazenyl)pentadione-2,4

\begin{tabular}{|l|c|c|c|c|c|c|c|c|c|}
\hline \multicolumn{1}{|c|}{ Complex } & $\mathrm{pH}_{\mathrm{opt}}$ & $\begin{array}{c}\lambda_{\mathrm{max},} \\
\mathrm{nm}\end{array}$ & $\begin{array}{c}\Delta \lambda, \\
\mathrm{nm}\end{array}$ & $\varepsilon \cdot 10^{3}$ & $C_{\mathrm{R}} / C_{\mathrm{Fe}}$ & $C_{\mathrm{DAM}} / C_{\mathrm{Fe}}$ & $\begin{array}{c}\text { The ratio of } \\
\text { components in } \\
\text { the composition }\end{array}$ & $\lg \beta$ & $\begin{array}{c}\text { The interval of obe- } \\
\text { ying to Beer's law, } \\
\mathrm{mkg} / \mathrm{ml}\end{array}$ \\
\hline $\mathrm{Fe}-\mathrm{R}$ & $4.5-5.0$ & 434 & 52 & $3.10 \pm 0.06$ & $2.5-10$ & & $1: 2$ & $5.76 \pm 0.10$ & $0.45-4.48$ \\
\hline $\mathrm{Fe}-\mathrm{R}-\mathrm{DAM}$ & $2.0-2.5$ & 476 & 94 & $6.00 \pm 0.10$ & $2.5-10$ & $1.5-8.0$ & $1: 2: 1$ & $14.65 \pm 0.26$ & $0.34-4.48$ \\
\hline
\end{tabular}

Table 2. Determination of iron in volcanic mountain rocks $(n=5, P=0.95)$

\begin{tabular}{|c|c|c|c|}
\hline Sample & Quantity of components according to passport, $\%$ & Found Fe, \% & $S_{r}$ \\
\hline I & $\begin{array}{l}\mathrm{TiO}_{2}-0.75 ; \mathrm{Fe}_{2} \mathrm{O}_{3}-4.52(\mathrm{Fe}-3.164) ; \mathrm{FeO}-0.88(\mathrm{Fe}-0.684) ; \mathrm{CaO}-5.88 \\
\mathrm{MgO}-1.50 ; \mathrm{P}_{2} \mathrm{O}_{5}-0.72 ; \mathrm{MnO}-0.02 ; \mathrm{K} 2 \mathrm{O}-4.00 ; \mathrm{Na}_{2} \mathrm{O}-5.40 ; \mathrm{In}_{2} \mathrm{O}_{3}-0.01 \\
\mathrm{Ga}_{2} \mathrm{O}_{3}-0.00945 ; \mathrm{Sc}_{2} \mathrm{O}_{3}-0.01 ; \mathrm{SeO}_{3}-0.05 ; \mathrm{REE}-0.70 ; \mathrm{H}_{2} \mathrm{O}-0.29 ; \mathrm{SiO}_{2}- \\
75.26055\end{array}$ & $3.846 \pm 0.114$ & 0.026 \\
\hline II & $\begin{array}{l}\mathrm{TiO}_{2}-0.70 ; \mathrm{Fe}_{2} \mathrm{O}_{3}-4.68(\mathrm{Fe}-3.276) ; \mathrm{FeO}-0.74(\mathrm{Fe}-0.575) ; \mathrm{CaO}-5.88 \\
\mathrm{MgO}-1.10 ; \mathrm{P}_{2} \mathrm{O}_{5}-0.71 ; \mathrm{MnO}-0.02 ; \mathrm{K}_{2} \mathrm{O}-3.92 ; \mathrm{Na}_{2} \mathrm{O}-5.60 ; \mathrm{In}_{2} \mathrm{O}_{3}-0.01 \\
\mathrm{Ga}_{2} \mathrm{O}_{3}-0.0102 ; \mathrm{Sc}_{2} \mathrm{O}_{3}-0.01 ; \mathrm{SeO}_{3}-0.05 ; \mathrm{REE}-0.30 ; \mathrm{H}_{2} \mathrm{O}-0.13 ; \mathrm{SiO}_{2}- \\
76.1398\end{array}$ & $3.866 \pm 0.102$ & 0.022 \\
\hline
\end{tabular}




\section{References}

1. Pilipenko A.T., Tananoiko M.M. Raznoligandnye i raznometallnye kompleksy i ikh primenenie $\mathrm{v}$ analiticheskoi himii. M.: Himiia, 1983. $224 \mathrm{~s}$.

2. Savvin S.B., Chernova R.K., Shtykov S.N. Poverkhnostno-aktivnye veshchestva. M.: Nauka, 1991. $251 \mathrm{~s}$.

3. Umland F., Iansen A., Tirig D., Viunsh G. Kompleksnye soedineniia v analiticheskoi himii. M.: Mir, 1975. $531 \mathrm{~s}$.

4. Liu Xian-Guo, Yang Wen-Hua, Wang Ping. Spectrophotometric determination of gallium SDM-phenylfluorone and cetytrimethylammonym bromide. Chin. J. Spectrosc. Lab. 2002. V.19. No 3. P. 317-319.

5. Filik Hayati, Tutem Esma. Use of the molybdenum thiocyanate-rhodamine $6 \mathrm{G}$ ternary complex for specrtophotometric determination molybdenum without extraction. Anal. chim. acta. 2004. V. 505. No 1. P.77-82.

6. Giulliarli U.A., Nagiev KH.D., Gambarov D.G., Chyragov F.M. Vzaimodeistvie tcirko-niia(IV) s 2,3,4-trigidroksifenilazo-5'-sulfonaftalinom v prisutstvii diantipirilmetana i ego gomologov. Zhurn. analit. himii. 2006. T. 61. No 6. C. 604-607.

7. Nagiev Kh.D., Espandi F.E., Alieva R.A., Giulliarli U.A., Chyragov F.M. Opredelenie mikrokolichestv zheleza v fruktakh. Analitika i kontrol. 2013. T. 17. № 1. C. 107-111.

8. Abiyeva A.Y., Ismiyev A.I., Nagiyev Kh.D., Chyragov F.M., Askerov R.K. Synthesis, crystal structure and research opportunities of 2,4-diacetyl-3-(3'nitrophenyl)-5-hydroxy-5-methylcyclohexanone. New Materials, Compounds and Applications. 2018. V. 2. No 1. P. 22-27.

9. Abiyeva A.Y., Aliyeva R.A., Nasibli A.H., Ismiyev A.I., Nagiyev Kh.J. Co-operation of iron(III) with 2,4-diacethyl-3-phenyl-5-methyl-5-hidroxihexanon in the presence of diantipyrylmethane and diantipyrylphenylmethane. East Eur. Scientific J. Chemia. 2016. No 6. C. 139-143.

10. Korostelev P.P. Prigotovlenie rastvorov dlia himiko-analiticheskikh rabot. M.: Nauka, 1964. $261 \mathrm{~s}$.

11. Bulatov M.I., Kalinkin N.P. Prakticheskoe rukovodstvo po fotometricheskim metodam analiza. L.: Himiia, 1986. $432 \mathrm{~s}$.

12. Astahov K.V., Verinikin V.B., Zimin V.I., Zverkova A.A. Spektrofotometricheskoe izuchenie kompleksoobrazovaniia nekotorykh redkozemelnykh elementov s nitrilouksusnoi kislotoi. Zhurn. Neorgan. ximii. 1961. T. 6. C. 2069-2076.

13. Batuner L.M., Pozin M.E. Matematicheskie metody v himicheskoi tekhnike. L.: Him. lit., 1963. 638 s.

\section{DəMIRİN(III) 3-((2-HIDROKSIFFENIL)DİAZENIL)PENTADIOON-2,4 VӘ DİANTİPİRILMETANLA SPEKTROFOTOMETRIK TOYINI}

\section{A.Y.Abiyeva, F.V.Quliyeva, X.C.Nağıyev, Ә.Q.Babayev, F.M.Çıraqov}

Diantipirilmetan iştirakında dəmirin(III) 3-((2-hidroksifenil)diazenil)pentadion-2,4-lə kompleks əmələ gətirməsi spektrofotometrik metodla tədqiq edimiş və təbii obyektlərdə onun mikromiqdarının təyini üçün yüksək seciliyə malik metodika işlənib hazırlanmışdır. Müəyyən edilmişdir ki, diantipirilmetan iştirakında dəmir(III) reaktivlə $\mathrm{pH} 2.0-2.5$ turşuluqlu mühitdə $\mathrm{Fe}(\mathrm{III})$ :R:DAM komponentləri nisbəti 1:2:1 olan intensiv rəngli qarışıqliqandlı kompleks əmələ gətirir. Qarışıliqandlı kompleksin əmələ gəlməsi udma spektrində eynilandlı kompleksin udma spektri ilə müqayisədə batoxrom sürüş̧ə və hiperxrom effektlə müşayiət olunur. Eyni- və qarışıqliqandlı komplekslərin optimal əmələ gəlmə şəraiti müəyyən edilmiş və əsas spektrofotometrik xarakteristikaları hesablanmışdır. Spektrofotometrik metodla komplekslərinin davamlılıq sabitləri təyin edilmiş və $\mathrm{Fe}(\mathrm{III})-\mathrm{R}-\mathrm{DAM}$ qarışıqliqandlı kompleksinin daha yüksək davamlılığa malik olduğu müəyyən edilmişdir: $\lg \beta(\mathrm{Fe}-\mathrm{R})=5.76 \pm 0.10 ; \lg \beta(\mathrm{Fe}-\mathrm{R}-\mathrm{DAM})=14.65 \pm 0.26$. Dəmirin(III) təyinin üçün yüksək seçiciliyə malik yeni spektrofotometrik metodika işlənib hazırlanmış və işlənmiş metodika vulkanik dağ suxurlarında onun mikromiqdarının təyini üçün tətbiq edilmişdir.

Açar sözlor: damir(III), 3-((2-hidroksifenil)diazenil)pentadion-2,4, diantipirilmetan, vulkanik dă̆ suxuru.

\section{СПЕКТРОФОТОМЕТРИЧЕСКОЕ ОПРЕДЕЛЕНИЕ ЖЕЛЕЗА(III) C 3-((2-ГИДРОКСИФЕНИЛ)ДИАЗЕНИЛ)ПЕНТАДИОНОМ-2,4 И ДИАНТИПИРИЛМЕТАНОМ}

А.Ю.Абиева, Ф.В.Кулиева, Х.Д.Нагиев, А.К.Бабаев, Ф.М.Чырагов

Спектрофотометрическим методом исследовано комплексообразование железа(III) с 3-((2-гидроксифенил)диазенил)пентадионом-2,4 в присутствии диантипирилметана и разработана высокоселективная методика определения его микроколичеств в природных объектах. Установлено, что при $\mathrm{pH}$ 2.0-2.5 в присутствии диантипирилметана железо(III) с реагентом образует интенсивно окрашенный смешанно-лигандный комплекс $\mathrm{Fe}(\mathrm{III})-\mathrm{R}-Д \mathrm{AM}$ c соотношением компонентов 1:2:1. При образовании смешанно-лигандного комплекса наблюдаются батохромные сдвиги и гиперхромный эффект в спектре поглощения по сравнению с бинарным комплексом. Установлены оптимальные условия образования и рассчитаны основные спектрофотометрические характеристики однородного и смешанно-лигандного комплекса железа(III). Спектрофотометрическим методом определены константы

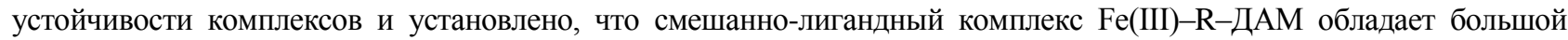
устойчивостью: $\lg \beta(\mathrm{Fe}-\mathrm{R})=5.76 \pm 0.10 ; \lg \beta(\mathrm{Fe}-\mathrm{R}-\mathrm{DAM})=14.65 \pm 0.26$. Разработанная нами новая методика применена для определения микроколичеств железа(III) в вулканогенных горных породах.

Ключевые слова: железо(III), 3-((2-гидроксифенил)диазенил)пентадиона-2,4, диантипирилметан, вулканогенные горные породы. 